\title{
Diffusion Interactions of Some Biologically Important Transition Metal Complexes on Micellar Properties of Sodium Dodecyl Sulphate
}

\author{
M. A. Hossain ${ }^{1}$, M. A. Rahman ${ }^{1}$ and M. A. Subhan ${ }^{1,2 *}$ \\ ${ }^{1}$ Department of Chemistry, Shah Jalal University of Science and Technology, Sylhet, Bangladesh \\ ${ }^{2}$ Depertment of Chemistry, Andong National University, South Korea
}

Received 12 July 2011, accepted in final revised form 17 October 2011

\begin{abstract}
The specific conductance of aqueous solutions of sodium dodecyl sulphate (SDS) was measured from 20 to $35{ }^{\circ} \mathrm{C}$ with an interval of $5{ }^{\circ} \mathrm{C}$ in the absence and presence of metal complexes such as $\left[\mathrm{Cr}(\mathrm{acac})_{2}\left(\mathrm{H}_{2} \mathrm{O}\right)_{2}\right] \mathrm{Cl}, \mathrm{K}_{3}\left[\mathrm{Fe}\left(\mathrm{C}_{2} \mathrm{O}_{4}\right)_{3}\right]$ and $\left(\mathrm{NH}_{4}\right)_{4}\left[\mathrm{Co}\left(\mathrm{C}_{6} \mathrm{H}_{5} \mathrm{O}_{7}\right)_{2}\right]$ at concentrations ranging from $2.0 \times 10^{-4}$ to $8.0 \times 10^{-4} \mathrm{M}$. The specific conductance rapidly increased at the pre-micellar region with increasing of temperature and concentration of SDS, but after critical micelle concentration (CMC) the rate of increase was slower. As the concentrations of metal complexes $\left[\mathrm{Cr}(\mathrm{acac})_{2}\left(\mathrm{H}_{2} \mathrm{O}\right)_{2}\right] \mathrm{Cl}, \mathrm{K}_{3}\left[\mathrm{Fe}\left(\mathrm{C}_{2} \mathrm{O}_{4}\right)_{3}\right]$ and $\left(\mathrm{NH}_{4}\right)_{4}\left[\mathrm{Co}\left(\mathrm{C}_{6} \mathrm{H}_{5} \mathrm{O}_{7}\right)_{2}\right]$ increased, the CMC of SDS decreased exponentially, which was sharp with increasing temperature. The CMC decreases due to the formation of pre-micellar aggregates of the positive counter ions of the complexes with dodecyl sulphate ions (DS') and hydrophobic interaction between ligands of complexes and hydrophobic tail of SDS. The pre-micellar aggregate formation was essentially influenced by the counter ions binding abilities to the anionic micelle. The effect of metal complexes on lowering the CMC of SDS was found to follow the order $\left[\mathrm{Cr}(\mathrm{acac})_{2}\left(\mathrm{H}_{2} \mathrm{O}\right)_{2}\right] \mathrm{Cl}<\mathrm{K}_{3}\left[\mathrm{Fe}\left(\mathrm{C}_{2} \mathrm{O}_{4}\right)_{3}\right]<\left(\mathrm{NH}_{4}\right)_{4}\left[\mathrm{Co}\left(\mathrm{C}_{6} \mathrm{H}_{5} \mathrm{O}_{7}\right)_{2}\right]$. Thermodynamics of metal complexes with SDS and parameters of micellization $\Delta G_{\text {mic }}^{\circ}$, $\Delta H_{\text {mic }}^{\circ}$ and $T \Delta S_{\text {mic }}^{\circ}$ were calculated.
\end{abstract}

Keywords: Surfactants; Sodium dodecyl sulphate; Critical micelle concentration; Premicellar aggregate; Hydrophobic interaction.

(c) 2011 JSR Publications. ISSN: 2070-0237 (Print); 2070-0245 (Online). All rights reserved.

doi: 10.3329/jsr.v4i1.7989 J. Sci. Res. 4 (1), 135-141 (2012)

\section{Introduction}

Surfactants, sometimes called surface-active agents or detergents, are among the most versatile chemicals available. Surfactants are amphiphilic molecules which undergo special type of self-assembly process, and the phenomenon is known as micellization. These have applications in many areas, including chemistry (chemical kinetics or equilibria), biology (as membrane mimetics) and are used to promote the dissociation of proteins from nucleic acids on extraction from biological material and in pharmacy to

*Corresponding author: subhan-che@sust.edu 
design drug action mechanism [1]. Model composed of amphiphilic materials and aggregated colloids provide a useful way for better understanding in many invaluable areas, such as, biochemistry, medicine, and pharmaceuticals as well as in catalysis [2, 3]. Several research groups $[4,5]$ have studied the kinetics of organic reactions in the presence of surfactant micelles as these can influence the rate of the chemical reactions incorporating the reactant molecules in micellar pseudophase. For couple of years, interests have grown to reveal the character of interactions between metal chelates and different types of surfactants. Daniel et al. [6] reported on micellar binding of $\mathrm{Cr}$ (III) complexes to SDS in air saturated solution and in $\mathrm{N}_{2}$-purged solution using lifetime measurements. Sumio et al. [7] showed the interaction of SDS with Fe(II) chelate and concluded that the association complexes are formed mainly by the hydrophobic interaction between the groups of the metal chelate and the hydrocarbon parts of surfactant anions. Furthermore, Oladega et al. [8] studied the binding of some Fe(II) complexes with cetyl trimethylammonium bromide and sodium dodecyl sulphate (SDS) and they made a conclusion that any of the surfactants confirms the predominance of hydrophobic interaction over electrostatic interaction in the evaluation of the micelle.

[Cr(acac $\left.)_{2}\left(\mathrm{H}_{2} \mathrm{O}\right)_{2}\right] \mathrm{Cl}$ and $\mathrm{K}_{3}\left[\mathrm{Fe}\left(\mathrm{C}_{2} \mathrm{O}_{4}\right)_{3}\right.$ are familiar compounds known to have vast coordination chemistries. $\mathrm{K}_{3}\left[\mathrm{Fe}\left(\mathrm{C}_{2} \mathrm{O}_{4}\right)_{3}\right.$ complex is a versatile compound to illustrate the principle of chemical equilibria [9]. Citric acid represents a class of carboxylic acids present in biological fluids and playing key roles in biochemical processes in bacteria and humans. Its ability to diverse coordination chemistries in aqueous media, in the presence of metal ions known to act as trace elements in human metabolism, earmarks its involvement in a number of physiological functions. Cobalt is known to be a central element of metabolically important biomolecule, such as $B_{12}$, and therefore its biospecification in biological fluids constitutes a theme worthy of chemical and biological perusal [10].

In the present work, our aim was to study the interaction of $\left[\mathrm{Cr}(\mathrm{acac})_{2}\left(\mathrm{H}_{2} \mathrm{O}\right)_{2}\right] \mathrm{Cl}$, $\mathrm{K}_{3}\left[\mathrm{Fe}\left(\mathrm{C}_{2} \mathrm{O}_{4}\right)_{3}\right]$ and $\left(\mathrm{NH}_{4}\right)_{4}\left[\mathrm{Co}\left(\mathrm{C}_{6} \mathrm{H}_{5} \mathrm{O}_{7}\right)_{2}\right]$ complexes with anionic surfactant SDS and to reveal the effect of these complexes on the micellar properties of SDS which was investigated based on specific conductance measurement, the widely used method to locate the CMC's of ionic surfactants.

\section{Experimental}

All reagents used for experiment were of analytical grade. Throughout the work deionised water was used previously distilled with potassium permanganate. [Cr(acac $\left.)_{2}\left(\mathrm{H}_{2} \mathrm{O}\right)_{2}\right] \mathrm{Cl}$ and $\mathrm{K}_{3}\left[\mathrm{Fe}\left(\mathrm{C}_{2} \mathrm{O}_{4}\right)_{3}\right.$ complexes were prepared by the same method as reported in the literature [9-10]. SDS from Merk (Germany) was used after purification by recrystallization using absolute ethanol.

\subsection{Method}

SDS solutions of specific concentrations were prepared from $50 \mathrm{mM}$ stock solution by 
appropriate dilution in double distilled water. The conductivity data were measured with a digital conductivity meter (Model- DDS-607, China). The calibration of the instrument was done with $0.01 \mathrm{M} \mathrm{KCl}$ solutions (specific conductance $=1.55 \times 10^{3} \mu \mathrm{S} \mathrm{cm}^{-1}$ at $30^{\circ} \mathrm{C}$ ) at regular time intervals and the electrode was cleaned with distilled water after each measurement. The cell constant was kept constant at 1.0 throughout the work. The CMC of SDS was determined by measuring specific conductance of solutions of particular concentrations of the complexes kept in a plastic beaker by dipping the electrode in solutions. The temperature of the system was kept constant within $\pm 0.1^{\circ} \mathrm{C}$ with the aid of a digital thermostat (Clifton, Nickel Electro, England).

\section{Results and Discussions}

\subsection{Interaction of metal complexes with SDS}

The effect of metal complexes on CMC of SDS at $30^{\circ} \mathrm{C}$ is illustrated in Fig. 1. As the concentration of the metal complexes increase gradually, there is a sharp decrease in CMC values from $8.20 \mathrm{mM}$. There have been inconsistent reports about the effect of metal complexes on the micelle formation of anionic surfactant in solution; one is that the effect is similar to that of a simple cation of the same charge [11-14], and the other claims that the CMC is greatly reduced $[15,16]$ and sometimes induces separation of viscous liquid phase [15]. Generally, the CMC of anionic surfactants should systematically decrease by the addition of an electrolyte [17-19]. Ponganis et al. [14] interpreted the turbidity observed in aqueous solutions of SDS containing $\left[\mathrm{Cu}(\mathrm{phen})_{2}\right]^{+}$below the CMC to arise from ion pair formation between the metal chelate ion and the polar head groups of the surfactant anions. Meisel et al. [11] compared the absorption spectra of $\left[\mathrm{Ru}(\mathrm{bpy})_{3}\right]^{2+}$ in aqueous SDS solutions with those in aliphatic alcohols, evidenced that $\left[\operatorname{Ru}(b p y)_{3}\right]^{2+}$ interacted with the hydrocarbon part rather than the polar head group of SDS. The association of the metal complexes to pre-micellar aggregates is fundamentally considered as hydrophobic interaction but electrostatic interaction is significant too.

The hydrophobic interaction between the hydrophobic tail of SDS and bulky ligands of metal complexes has predominance over the electrostatic interaction and the hydrophobic interaction is related to the type of ligands involved. Oladega et al. [8] showed that the positive charge on $\left[\mathrm{Fe}(\text { phen })_{3}\right]^{2+}$ makes it least hydrophobic than the cyano neutral complexes. The CMC varies in the order $\left.\left[\mathrm{Fe}\left(4,7-\mathrm{Me}_{2} \text { phen }\right)_{2}(\mathrm{CN})_{2}\right]<\mathrm{Fe}(\text { phen })_{2}(\mathrm{CN})_{2}\right]<$ $\left.\left[\mathrm{Fe}(\mathrm{phen})_{3}\right]^{2+}\right][8,20-22]$. The relatively weak micellar interaction of the uncharged [Co(5- $\mathrm{SO}_{3}$-phen $)_{3}$ ] complex with the anionic surfactant is attributed to electrostatic repulsion resulting from the fairly high negative charge density associated with the $\mathrm{SO}_{3}{ }^{-}$substituent. This is consistent with the even more marked rate of inhibition observed with the anionic oxidant, $\left[\mathrm{Co}(\text { dipic })_{2}\right]^{-}$, where reaction is again occuring at the micelle-water interface between micelle-solubilized reductant and $\mathrm{Co}$ (dipic) ${ }^{-}$in the aqueous phase [23]. The hydrophobic ligand structure can effectively weaken coulombic forces by promoting solubilization in the micellar interior. 


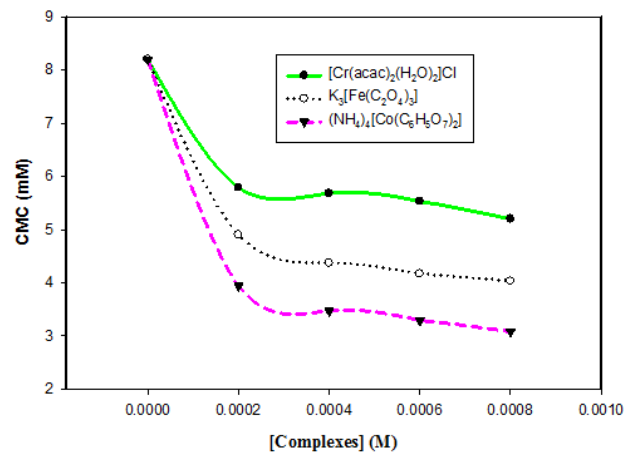

Fig. 1. Variation in CMC of SDS against different concentrations of the metal complexes.

A larger radius of hydration will result in greater ion separation. It has been found that, for a given hydrophobic tail and anionic head group, the CMC decreases in the order: $\mathrm{Li}^{+}$ $>\mathrm{Na}^{+}>\mathrm{K}^{+}>\mathrm{Cs}^{+}>\mathrm{NH}_{4}{ }^{+}$. The larger the hydrated radius of the counter ion, the weaker the degree of binding to the micelle. This is in direct contrast to our present work that the decrease in CMC values of SDS with increasing concentrations of $\mathrm{K}_{3}\left[\mathrm{Fe}\left(\mathrm{C}_{2} \mathrm{O}_{4}\right)_{3}\right.$ and $\left(\mathrm{NH}_{4}\right)_{4}\left[\mathrm{Co}\left(\mathrm{C}_{6} \mathrm{H}_{5} \mathrm{O}_{7}\right)_{2}\right]$ occurred because of added counter ions $\left(\mathrm{K}^{+}\right.$and $\left.\mathrm{NH}_{4}{ }^{+}\right)$occupied the stern layer preferentially to $\mathrm{Na}^{+}$ion due to smaller hydrated radius which minimized the electrostatic repulsion of the closely packed charged head groups at micellar surface and thereby stabilizing the micellar structure.

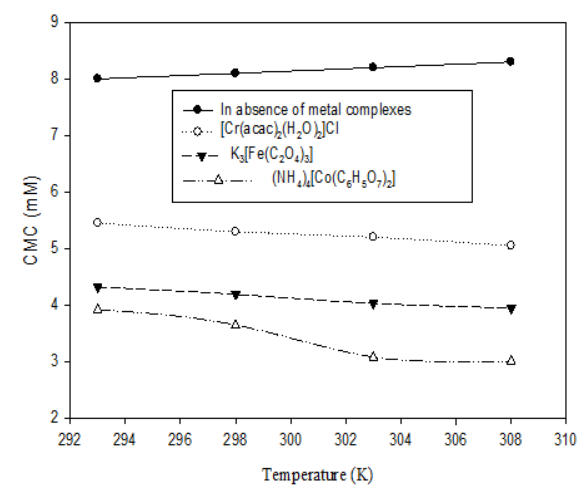

Fig. 2. Variation in CMC of SDS at different temperatures in presence of the metal complexes.

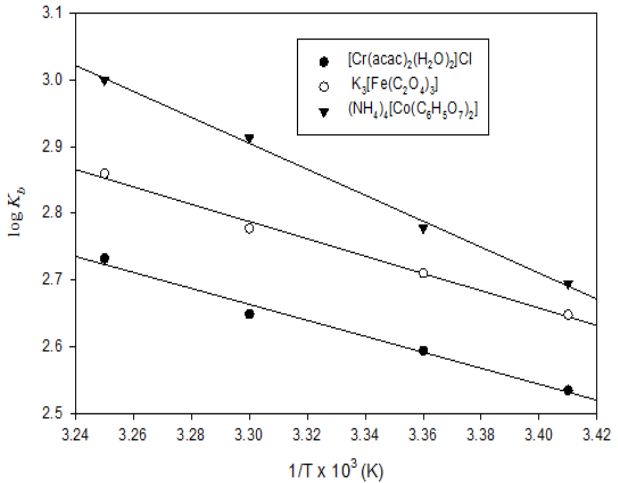

Fig. 3. Variation of $\log _{\mathrm{b}}$ of metal complexes as a function of $1 / \mathrm{T}$.

The micelle formation was increasingly favored at increasing concentrations of added cations in the stern layer and consequently it took place at lower surfactant concentrations. The decrease in CMC value was greater for $\left(\mathrm{NH}_{4}\right)_{4}\left[\mathrm{Co}\left(\mathrm{C}_{6} \mathrm{H}_{5} \mathrm{O}_{7}\right)_{2}\right]$ than $\mathrm{K}_{3}\left[\mathrm{Fe}\left(\mathrm{C}_{2} \mathrm{O}_{4}\right)_{3}\right.$ complex due to smaller hydrated radius of $\mathrm{NH}^{4+}$ than $\mathrm{K}^{+}$. The decrease in CMC value for 
[Cr(acac $\left.)_{2}\left(\mathrm{H}_{2} \mathrm{O}\right)_{2}\right] \mathrm{Cl}$ complex might be due to the hydration of the chelate (in both outer and inner coordination sphere) which made the complex ion even more larger in radius and hence it is easily understandable that micellization was hindered resulting slowest decrease compared to $\mathrm{K}_{3}\left[\mathrm{Fe}\left(\mathrm{C}_{2} \mathrm{O}_{4}\right)_{3}\right.$ and $\left(\mathrm{NH}_{4}\right)_{4}\left[\mathrm{Co}\left(\mathrm{C}_{6} \mathrm{H}_{5} \mathrm{O}_{7}\right)_{2}\right]$ complexes. We may also consider the hydrophobic interaction of the hydrophobic ligands of metal complexes and hydrophobic tail of SDS which solubilized into the micellar interior and thus facilitates micellization.

\subsection{Thermodynamics of metal complexes-SDS systems}

A clear understanding of the process of micellization is necessary for rational explanation of the effects of structural and environmental factors on the value of CMC and for predicting the effects on it of new structural and environmental variations. The interaction of metal complexes with SDS was studied conductometrically. The specific conductance of SDS was recorded at four different temperatures with an interval of $5^{\circ} \mathrm{C}$ ranging from 20 to $35^{\circ} \mathrm{C}$ in the absence and presence of $8.0 \times 10^{-4} \mathrm{M}$ concentration of metal chelates in aqueous solution. Fig. 2 represents the variation in CMC of SDS in presence and absence of metal complexes, which depicts that as the temperature is increased the CMC decreases sharply in presence of complexes. This might be explained by the fact that as the temperature is increased there would be a decrease in radius of the hydrated counter ions and hence the value of binding constant increased as given in Table 1 . Table 2 represents the micellization parameters. $\Delta G^{\circ}{ }_{\text {mic }}$, free energy change of micellization, $\Delta H^{\circ}{ }_{\text {mic }}$, enthalpy change of micellization and $\Delta S_{\text {mic }}^{\circ}$, entropy change of micellization calculated according to the equations and with the method of least squares $\left(r^{2}=0.982\right)$ mentioned in the literature [24-27]. The free energy of micellization was calculated using the following equation :

$$
\Delta G^{\circ}{ }_{m i c}=(1+f) R T \ln C M C
$$

where, ' $f$ ' is the degree of counter ion binding and the value of ' $\alpha$ ' (known as the degree of counter ion dissociation), was calculated from the slope ratio of the straight lines at post-micellar to pre-micellar regions. As a result, the values of $f$ were calculated by subtracting the values of $\alpha$ from unity. The values of binding constant $\left(K_{b}\right)$ were derived from the following relation

$$
\Delta G_{\text {mic }}^{\circ}=-2.303 R T \log K_{b}
$$

From the well-known vant't Hoff equation

$$
\log K_{b}=\frac{\Delta H_{\text {mic }}^{0}}{-2.303 R T}
$$


Thus, from the plot of $\log K_{b}$ against $\frac{1}{T}$ slope $\left(-\Delta H_{\text {mic }}^{\circ} / 2.303 R\right)$ was obtained (Fig. 3), from which the enthalpy change of micellization, $\Delta H^{\circ}$ mic was calculated. The negative values of $\Delta G_{\text {mic }}^{\circ}$ were found to increase with increasing temperature, i.e. the formation of micelle was more spontaneous with increase of temperature [28]. The greater values of $T \Delta S_{\text {mic }}^{\circ}$ largely contributed to the negative values of $\Delta G_{\text {mic }}^{\circ}$, which revealed that the spontaneous micellization process is entropically controlled.

Table 1. Calculated values of degree of ionization $(\alpha)$, degree of counter ion binding $(f)$, binding constant $\left(K_{b}\right)$ for the micellization of SDS in presence of metal complexes.

\begin{tabular}{lccccccccccc}
\hline Temperature & \multicolumn{3}{c}{$\left[\mathrm{Cr}(\mathrm{acac})_{2}\left(\mathrm{H}_{2} \mathrm{O}\right)_{2}\right] \mathrm{Cl}$} & \multicolumn{3}{c}{$\mathrm{K}_{3}\left[\mathrm{Fe}\left(\mathrm{C}_{2} \mathrm{O}_{4}\right)_{3}\right]$} & \multicolumn{3}{c}{$\left(\mathrm{NH}_{4}\right)_{4}\left[\mathrm{Co}\left(\mathrm{C}_{6} \mathrm{H}_{5} \mathrm{O}_{7}\right)_{2}\right]$} \\
$T(\mathrm{~K})$ & $\alpha$ & $f$ & $\log K_{b}$ & $\alpha$ & $f$ & $\log K_{b}$ & $\alpha$ & $f$ & $\log K_{b}$ \\
\hline 293 & 0.88 & 0.12 & 2.53 & 0.76 & 0.24 & 2.65 & 0.70 & 0.30 & 2.70 \\
298 & 0.86 & 0.14 & 2.59 & 0.74 & 0.26 & 2.71 & 0.67 & 0.33 & 2.78 \\
303 & 0.84 & 0.16 & 2.65 & 0.73 & 0.27 & 2.78 & 0.64 & 0.36 & 2.91 \\
308 & 0.81 & 0.19 & 2.73 & 0.71 & 0.29 & 2.86 & & 0.63 & 0.37 & 3.00 \\
\hline
\end{tabular}

Table 2. Thermodynamic parameters in $\mathrm{kJ} \mathrm{mol}^{-1}$ for SDS in aqueous solution in presence of metal complexes.

\begin{tabular}{|c|c|c|c|c|c|c|c|c|c|}
\hline \multirow{2}{*}{$\begin{array}{l}\text { Temperature } \\
T(\mathrm{~K})\end{array}$} & \multicolumn{3}{|c|}{$\left[\mathrm{Cr}(\mathrm{acac})_{2}\left(\mathrm{H}_{2} \mathrm{O}\right)_{2}\right] \mathrm{Cl}$} & \multicolumn{2}{|c|}{$\mathrm{K}_{3}\left[\mathrm{Fe}\left(\mathrm{C}_{2} \mathrm{O}_{4}\right)_{3}\right]$} & \multicolumn{4}{|c|}{$\left(\mathrm{NH}_{4}\right)_{4}\left[\mathrm{Co}\left(\mathrm{C}_{6} \mathrm{H}_{5} \mathrm{O}_{7}\right)_{2}\right]$} \\
\hline & $-\Delta G_{m i c}^{\circ}$ & $\Delta H_{\text {mic }}^{\circ}$ & $T \Delta S_{\text {mic }}^{\circ}$ & $-\Delta G_{\text {mic }}^{\circ}$ & $\Delta H_{\text {mic }}^{\circ}$ & $T \Delta S_{\text {mic }}^{\circ}$ & $\Delta G_{\text {mic }}^{\circ}$ & $\Delta H_{\text {mic }}^{\circ}$ & $\Delta S_{\text {mic }}^{\circ}$ \\
\hline 293 & 14.22 & & 50.90 & 14.86 & & 42.43 & 15.12 & & 39.77 \\
\hline 298 & 14.80 & +36.68 & 51.48 & 15.47 & +27.57 & 43.04 & 15.86 & +24.65 & 40.51 \\
\hline 303 & 15.37 & & 52.05 & 16.12 & & 43.69 & 16.90 & & 41.55 \\
\hline 308 & 16.12 & & 52.80 & 16.87 & & 44.44 & 17.70 & & 42.35 \\
\hline
\end{tabular}

\section{Conclusion}

The CMC values of SDS were found to decrease exponentially from $8.10 \mathrm{mM}$ to 5.20 $\mathrm{mM}, 4.03 \mathrm{mM}$ and $3.08 \mathrm{mM}$ in presence of $\left[\mathrm{Cr}(\mathrm{acac})_{2}\left(\mathrm{H}_{2} \mathrm{O}\right)_{2}\right] \mathrm{Cl}, \mathrm{K}_{3}\left[\mathrm{Fe}\left(\mathrm{C}_{2} \mathrm{O}_{4}\right)_{3}\right]$ and $\left(\mathrm{NH}_{4}\right)_{4}\left[\mathrm{Co}\left(\mathrm{C}_{6} \mathrm{H}_{5} \mathrm{O}_{7}\right)_{2}\right]$ complexes, respectively, with increase in their concentrations from $2.0 \times 10^{-3} \mathrm{M}$ to $8.0 \times 10^{-3} \mathrm{M}$ at $30^{\circ} \mathrm{C}$. As the temperature increased from $20^{\circ} \mathrm{C}$ to $35^{\circ} \mathrm{C}$, CMC steadily decreased in the presence of complexes, which was due to electrostatic interaction between hydrated counter ions and anioic micelle. Temperature increase caused reduction in radius of hydrated counter ions, which in turn reduced repulsion between closely packed head groups, that favoured the micelle formation, evident from gradual increase in binding constant. Furthermore, thermodynamic parameters $\left(\Delta G_{\text {mic }}^{\circ}\right.$, 
$\Delta H_{\text {mic }}^{\circ}$ and $T \Delta S_{\text {mic }}^{\circ}$ ) calculated for metal complexes-SDS systems revealed that the micellization was entropically controlled.

\section{References}

1. P. Taboada, D. Attwood, J. M.Ruso, M. Garcia, F. Sarmiento, and V. Mosquera, J. Colloid Interface Sci. 220, 288 (1999). http://dx.doi.org/10.1006/jcis.1999.6545

2. F. Akhtar and M. A. Hoque, J. Bang.Chem. Soc. 19, 88 (2006).

3. D. Myers, Surfaces, Interfaces and Colloids (VCH Publisher, New York, 1991) p. 59.

4. S. Bhattacharya and V.P. Kumar, Langmuir 21, 71 (2005). http://dx.doi.org/10.1021/la048858f

5. L. Zakharova, F. Valeeva, A. Zakharov, A. Ibragimova, L. Kudryavtseva and H. Harlampipidi, J. Colloid Interface Sci. 263, 597 (2003). http://dx.doi.org/10.1016/S0021-9797(03)00343-6

6. P. Daniel, A. A. Gerardo, and E. G. Héctor, J. Colloid Interface Sci. 215, 16 (1999). http://dx.doi.org/10.1006/jcis.1999.6180

7. O. Sumio, T. Satoshi, I. Shoichi, and Y. Hideo, J. Colloid Interface Sci. 91, 439 (1983). http://dx.doi.org/10.1016/0021-9797(83)90357-0

8. O. S. Oladega, O. S. Owoyomi, and I. Jide, Arch. App. Sci. Res. 2, 7 (2010).

9. G. Gabriel and S. Miquel, J. Chem. Edu. 81, 1193 (2004). http://dx.doi.org/10.1021/ed081p1193

10. M. Matzapetakis, M. Dakanali, C. P.Rapatopoulou, V. Tangoulis A. Terzis, N. Moon, J. Giapintzakis, and A. Salifoglou, JBIC 5, 469 (2000). http://dx.doi.org/10.1007/s007750050007

11. D. Meisel, M. S. Matheson, and J. Rabini, J. Am. Chem. Soc. 100, 117 (1978). http://dx.doi.org/10.1021/ja00469a020

12. J. Holzwarth, W. Knoche, and B. H. Robinson, Ber. Bunsenges. Phys. Chem. 82, 1001 (1978).

13. S. Diekmann and J. Frahm, J. Chem. Soc. Faraday Trans. 175, 2199 (1979).

14. K. V. Ponganis, M. A. de Araujo, and H. L Hodges, Inorg. Chem. 19, 2704 (1980). http://dx.doi.org/10.1021/ic50211a044

15. S. Kratohvil, K. Shinoda, and E. Matijevic, J. Colloid Interface Sci.72, 106 (1979). http://dx.doi.org/10.1016/0021-9797(79)90186-3

16. J. -R. Cho and H. Morawetz, J. Am.Chem. Soc. 94, 375 (1972). http://dx.doi.org/10.1021/ja00757a011

17. M. L. Corrin, and W. D. Harkins, J. Am. Chem. Soc. 69, 683 (1947). http://dx.doi.org/10.1021/ja01195a065

18. S. Ozeki, S. Tachiyashiki, S. Ikeda, Hideo Yamatera. J. Colloid Interface Sci. 91, 430 (1983).

19. S. Ozeki and S. Ikeda, Bull. Chem.Soc. 53, 1832 (1980). http://dx.doi.org/10.1246/bcsj.53.1832

20. S. Tachiyashiki and H.Yamatera, Bull Chem. Soc. 57, 1070 (1984). http://dx.doi.org/10.1246/bcsj.53.1832

21. Y. Masuda, and H. Yamatera, Bull Chem. Soc. 57, 58 (1984). http://dx.doi.org/10.1246/bcsj.57.1026

22. S. Tachiyashiki and H. Yamatera, Bull. Chem. Soc. 57, 759 (1984). http://dx.doi.org/10.1246/bcsj.57.1070

23. M. D. Keith, H. Abul, R. R. Bayne, M. O. Iris Jr., and K. Peter, Inorg.Chem. 33, 1741 (1994). http://dx.doi.org/10.1021/ic00087a004

24. Y. Moroi, Micelles - Theoretical and Applied Aspects (Plenum Press, New York, 1992).

25. P. Mukerjee, Adv. Colloid Interface Sci. 1, 242 (1967). http://dx.doi.org/10.1016/0001-8686(67)80005-8

26. K. Mukerjee, D. C. Mukerjee, and S. P. Moulik, J. Phys. Chem. 98, 4713 (1994). http://dx.doi.org/10.1021/j100068a037

27. S. Ghosh, J. Colloid Interface Sci. 244, 128 (2001). http://dx.doi.org/10.1006/jcis.2001.7855

28. M. N. Islam, M. A. Hoque, M. A. Goni, F. Akthtar, M. A. Khan, and M. G. Ahmed, J. Bang. Chem. Soc. 20 (1) 35 (2007). 